\title{
INFLUENCE OF AERODYNAMIC TRAILER DEVICES ON DRAG REDUCTION MEASURED IN A WINDTUNNEL
}

\section{WPŁYW WYPOSAŻENIA AERODYNAMICZNEGO NACZEP NA ZMNIEJSZENIE OPORU POWIETRZA MIERZONEGO W TUNELU AERODYNAMICZNYM}

\begin{abstract}
The value of aerodynamic drag is the largest, when a vehicle is moving with higher velocity. It seems that drag reduction is the most important step for reducing the fuel consumption of haulage trailer sets. Using aerodynamic trailer devices is one of many ways for reduction of fuel consumption. This paper deals with experimental measuring of the truck set model in a wind tunnel. The scale of the model was 1/24. Resultant values of the drag reduction for chosen aerodynamic devices are discussed at the end of the paper.
\end{abstract}

Keywords: aerodynamic trailer device, drag counts, truck trailer, wind tunnel.

\begin{abstract}
Wartość oporu aerodynamicznego jest największa gdy pojazd porusza się z większa prędkościa. Wydaje się, że redukcja oporu jest najważniejszym krokiem do zmniejszenia zużycia paliwa zestawów transportowych zawierajacych naczepy. Zastosowanie wyposażenia aerodynamicznego naczep jest jednym z wielu sposobów na zmniejszenie zużycia paliwa. Niniejszy artykut poświęcony jest eksperymentalnym pomiarom modelu zestawu ciagnika z naczepa w tunelu aerodynamicznym. Skala modelu wynosita 1:24. Uzyskane wartości zmniejszenia oporu powietrza dla wybranych elementów wyposażenia aerodynamicznego omówiono w końcowej części pracy.
\end{abstract}

Stowa kluczowe: wyposażenie aerodynamiczne naczep, pomiary oporu, naczepa, tunel aerodynamiczny

\section{Introduction}

The moving of road vehicles is the biggest consumer of energy in the transport duty. So in this area it is still possible to reach some rising effectiveness despite the significant progress of the last years. In Europe the highest speed limit for HGVs is $90 \mathrm{~km} \times \mathrm{h}^{-1}$. The biggest share of driving performance is done on motorways and highways at the velocity of over $80 \mathrm{~km} \times \mathrm{h}^{-1}$. At this velocity the biggest resistance of all driving resistances acting on moving vehicle is the aerodynamic drag, which anticipates the rolling resistance at the velocity of $80 \mathrm{~km} \times \mathrm{h}^{-1}$. If we consider a tractor-trailer set $(30000 \mathrm{~kg}$ gross mass) with all operational characteristics of common values, so at the velocity of $90 \mathrm{~km} \times \mathrm{h}^{-1}$ the representation of each resistance power is: aerodynamic drag power $68 \mathrm{~kW}(47.5 \%)$, rolling resistance power 58 $\mathrm{kW}(40.5 \%)$, powertrain losses power $17 \mathrm{~kW}(12 \%)$.

This proportion points at the importance of raising the effectiveness of moving vehicle by reducing the aerodynamic drag $[1,3,5,9]$.

\section{Boundary Layer Wind Tunnel (BLWT)}

The measurement was done in the wind tunnel (Fig. 1), which belongs to the Slovak Technical University in Bratislava (The Faculty of Civil Engineering).

Universal BLWT tunnel contains two operating spaces - the front space (FOS) and the rear space (ROS). It is a vacuum tunnel with an opened circuit of air flow. The air is induced in its front part. Then is comes into the FOS where the uniform non-gradient wind flow with fluctuation less than $5 \%$ is created. The FOS is suitable for the analysis of uniform non-gradient wind flow with the velocity up to 32 $\mathrm{m} \times \mathrm{s}^{-1},[4,10]$

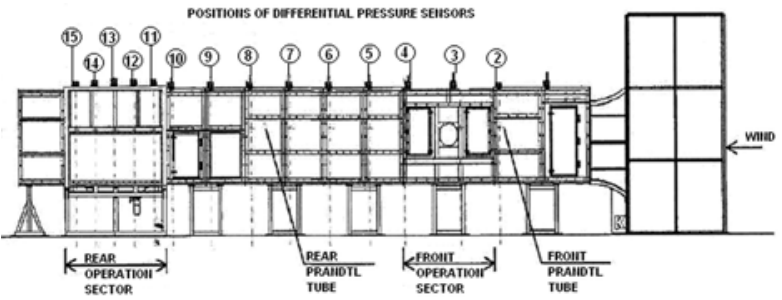

Fig. 1. Scheme of BLWT tunnel with positions of measuring devices [4]

\section{Measuring Devices}

Differential Pressure Sensors were placed at the cover along the tunnel in height of $1150 \mathrm{~mm}$ from tunnel floor. They were used for permanent monitoring of pressures inside the tunnel. Each sensor had two measuring points. Resultant value of pressure was calculated as the average from both values.

Prandtl tubes were placed in the tunnel (1st in FOS, 2nd in ROS). It determined the value of wind velocity by method of different between values of pressure in two places located on the cover of probe.

Almeo Type MA25902 with Thermo-Anemometer Probe Type FVAA935TH5K2 was used for the measurement of wind velocity $[4,10]$.

\section{Measurement and Evaluation}

Aerodynamic drag or air drag - these expressions are common as direct wind resistance, too. This is the force, which causes the resistance acting during a vehicle is moving. For the equation this resistance the Eq. 1 is used. 


$$
\mathrm{F}_{\mathrm{W}}=\frac{1}{2} \cdot \rho_{a} \cdot C_{d} \cdot S \cdot v^{2}
$$

Where: $\quad \mathrm{F}_{\mathrm{W}}-$ aerodynamic drag; wind resistance $[\mathrm{N}]$,

$$
\begin{array}{ll}
\rho_{\mathrm{a}} & - \text { air density }\left[\mathrm{kg} \times \mathrm{m}^{-3}\right], \\
\mathrm{C}_{\mathrm{d}} & - \text { drag coefficient }[-], \\
\mathrm{S} & - \text { frontal vehicle area }\left[\mathrm{m}^{2}\right], \\
\mathrm{v} & - \text { velocity of wrapping air }\left[\mathrm{m} \times \mathrm{s}^{-2}\right] .
\end{array}
$$

The principle is the direct measuring of the wind force (aerodynamic drag) which is acting on a vehicle model through blowing wind (Fig. 2, Fig. 3). Its value is influenced by current air conditions (air pressure and air temperature). The vehicle shape and size and the most important element is the velocity of the wrapping wind $[5,12,19]$.

This drag is directly proportional to the multiple of mentioned elements (Eq. 1). It is possible to change the only one element from the Eq. 1 . It is the drag coefficient $C_{d}$. Air density is a dynamical changing natural dimension that cannot be influenced by a human being. The vehicle size is limited by legislation and it is using on the edge. Downsizing is not acceptable because of the vehicle volume effectiveness. The vehicle velocity is an important element in the transport duties since it depends on the delivery time. It is possible to change only the vehicle shapes and they relate to the $\mathrm{C}_{\mathrm{d}}$. The coefficient expresses fluency of the wind wrapping $[6,8,20]$.

A number of physical data was read by detection devices during the measurement for precise determination of results. Especially the atmospheric pressure and air temperature were measured. From these values the instantaneous air density $\rho_{\mathrm{V}}$ were calculated. The speed of the airflow was measured by Prandtl tubes in several places in the tunnel and anemometer was used directly at the site wrapping around the model with four levels within the height of the model. Therefore it was possible to determine the mean velocity of the air, which was used in the calculations below.

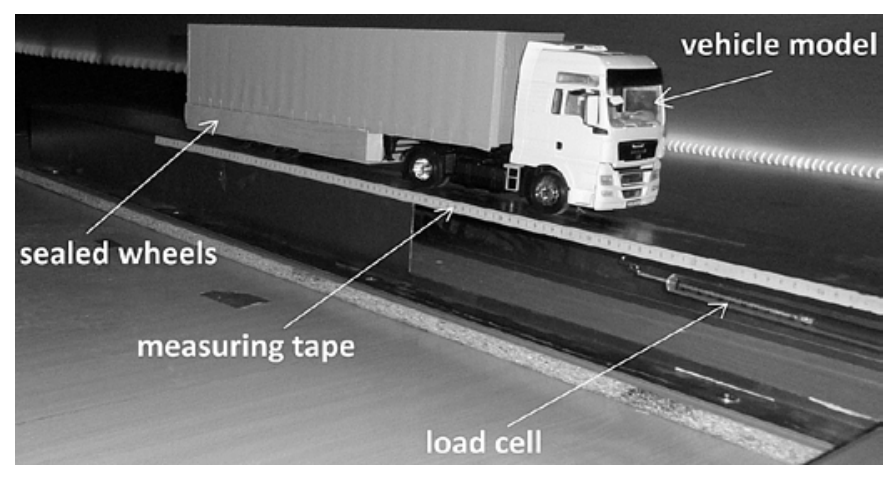

Fig. 2. Measuring apparatus

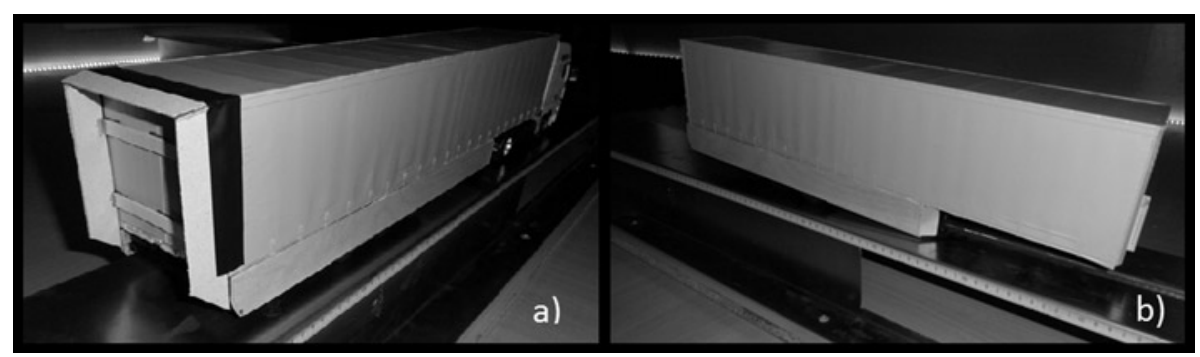

Fig. 5. Aerodynamic devices: a) combination of sealed wheels and tail, b) sealed wheels Fidth due to the scale model of the $1 / 24$ the size of both diensions. Thus the area represents $1 / 576$ of the real vehicle surface.

The wind resistance was measured by a load cell placed in the model preparation (Fig. 3). Mechanical load cell was equipped with a spring of linear characteristic and reached a measurement range of 0 $\mathrm{N}$ to $5 \mathrm{~N}$ with accuracy of $0.05 \mathrm{~N}$.

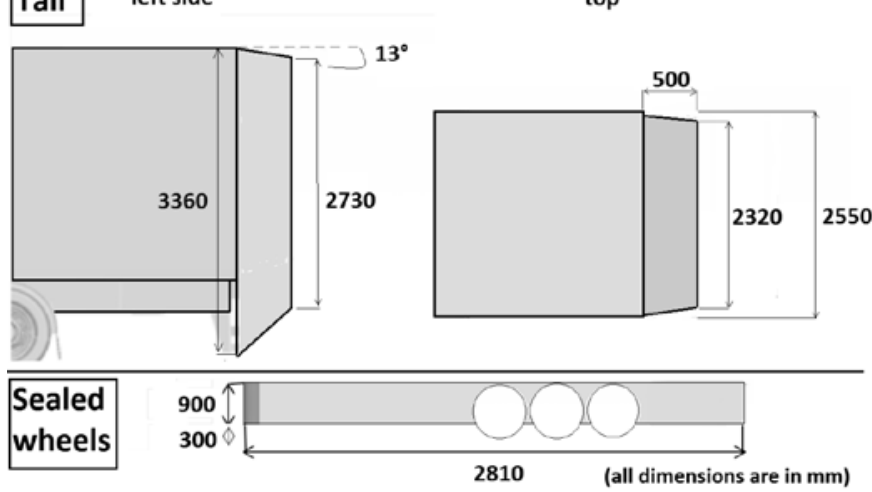

Fig. 4. Dimensions of aerodynamic devices

Tail

\section{Aerodynamic Devices}

The scopes of this measurement were two types of devices (Fig. 4). They were chosen because of the present trend of using these devices. The following devices have been chosen: sealed wheels, tail and combination of them.

Nowadays many measurements are done to describe the influence of these devices on the truck fuel consumption. Some transport companies already use sealed wheels on a part of the trailers and the trailer producers offer them as the optional trailer trim. But using the tail is not possible because of current legislation (length of truck sets). The new European legislation is in preparation, which allows this aerodynamic tail. The actual truck length will be about $500 \mathrm{~mm}$ longer.

The dimensions pointed on the Fig. 4 repre-

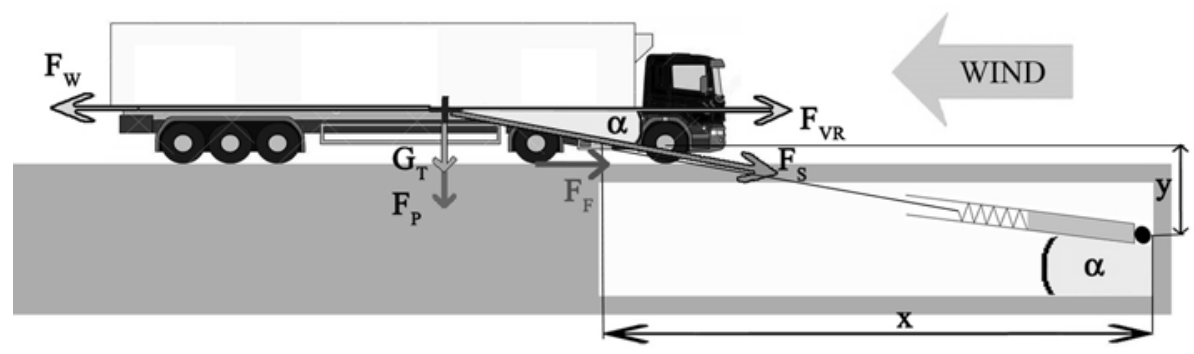
sent the devices of the real size in millimetres. Such devices were used on the model as well as their dimensions are scaled in $1 / 24$. Devices were made personally from soft wood (spruce) and attached to the model by a double - sided tape (Fig. 5).

\section{Conclusion}

During the measurement air pressure reached the values $99360-99460 \mathrm{~Pa}$ and air temperature was $(24 \div 24.4)^{\circ} \mathrm{C}$. Thanks to the steady conditions approximate value of air density was $1.196 \mathrm{~kg} \times \mathrm{m}^{-3}$. 
Each examined state (2 aerodynamic devices, their combination and reference "mass-produced" vehicle model) was measured for two cases of wind yaw angle $-0^{\circ}$ and $5^{\circ}$.

The velocity of wind flow was regulated by the frequency of two electric motors in the tunnel. All measurements were repeated for three frequencies (velocities) $-28 \mathrm{~Hz}, 32 \mathrm{~Hz}$ and $34 \mathrm{~Hz}$. These values correspond to following wind velocities $-15.48 \mathrm{~m} \times \mathrm{s}^{-1}, 17.28 \mathrm{~m} \times \mathrm{s}^{-1}$ and $18.08 \mathrm{~m} \times \mathrm{s}^{-1}$.

The model is resting on its wheels which are rotatable mounted. This fact was used and the model was pushed on the wheels by blowing wind in its direction. The model is equipped with rubber wheels. They cause rolling resistance. Also friction losses of wheel shafts represent resistance to movement of the vehicle. These resistive forces were measured after the measurement by hydraulic cylinder (laboratory equipment of the Department of Road and Urban Transport) and load cell. Using the cylinder, the model was driven by a very slow rate evenly over the measuring mat, so the rolling resistance value was given. This was done with multiple burdens placed on the model. Since cosine force component FS (Fig. 3) also creates additional downforce on the model surface.

The exact value of the angle $\alpha$ was determined by the distance between clamping load cell for measuring surface and clamping the model and the height difference of the two points. This distance was measured by using the measuring tape mounted on the substrate under the measurement model (Fig. 2).

During the measurement load cell senses the force $F_{S}$ which is not identical with the force of the wind, but must be recalculated due to the diversion load cell angle from the horizontal plane and the rolling resistance of tires.

$$
\begin{gathered}
F_{W}=F_{V R}+F_{f} \\
F_{W}=F_{S} \cdot \cos \alpha+\left(G_{T}+F_{P}\right) \cdot f \\
F_{W}=F_{S} \cdot \cos \alpha+\left(G_{T}+F_{S} \cdot \sin \alpha\right) \cdot f
\end{gathered}
$$

where: $\mathrm{f}$ - rolling resistance coefficient related for each experiment; other signs are described in Fig. 3.

After substituting Eq. 2 into the Eq. 1 we will obtain the resultant equation (Eq. 3). According to it the drag coefficient $\mathrm{C}_{\mathrm{d}}$ was calculated by inserting measured individual values.

$$
C_{d}=2 \cdot \frac{\left[F_{S} \cdot \cos \alpha+\left(G_{T}+F_{S} \cdot \sin \alpha\right) \cdot f\right]}{\rho_{a} \cdot S \cdot v^{2}}
$$

The measurement was performed in two cases namely the yaw angle of $0^{\circ}$ and of $5^{\circ}$. Several angles used to be examined in similar measurements. Their impact is expressed in the weighted average. However, the most relevant of which are right angles $0^{\circ}$ and $5^{\circ}$. The yaw angle is affected mainly by the strength and direction of the blowing wind while driving vehicle. In still air or direct headwind shall take this angle to $0^{\circ}$. Resulting yaw angle increases with increasing angle and speed of blowing wind $[2,15,16]$,

Table 1. Evaluation of measured values

\begin{tabular}{|l|c|c|c|c|c|c||}
\hline \multicolumn{1}{|c|}{ Device } & $C_{d}$ yaw $0^{\circ}$ & $C_{d}$ yaw 5 & $C_{d}$ (weighted) & DC yaw 0 & DC yaw 5 & DC (weighted) \\
\hline Reference model & 0.563 & 0.627 & 0.606 & - & - & - \\
\hline Sealed wheels & 0.521 & 0.606 & 0.578 & -43 & -21 & -28 \\
\hline Tail & 0.521 & 0.620 & 0.587 & -43 & -7 & -19 \\
\hline Combination & 0.479 & 0.570 & 0.540 & -85 & -57 & -66 \\
\hline
\end{tabular}

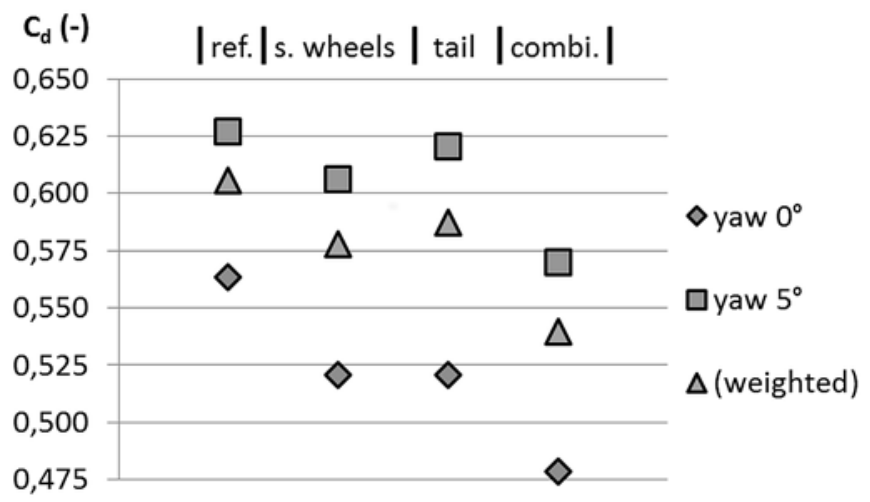

Fig. 6. Drag coefficient

$$
C_{d w}=1 / 3 C_{d 0}+2 / 3 C_{d 5}
$$

where: $C_{\mathrm{dw}}$ - weighted drag coefficient [-],

$\mathrm{C}_{\mathrm{d} 0}$ - drag coefficient at yaw $0^{\circ}[-]$,

$\mathrm{C}_{\mathrm{d} 5}$ - drag coefficient at yaw $5^{\circ}[-]$.

The column values (Fig. 7) represent the reducing of aerodynamic drag in units designated as DC (Drag counts - unit air resistance). They represent thousands of times the difference of the coefficients $\mathrm{Cd}$ for reference vehicle and vehicle with devices. This is a simplified labelling of drag coefficients difference.

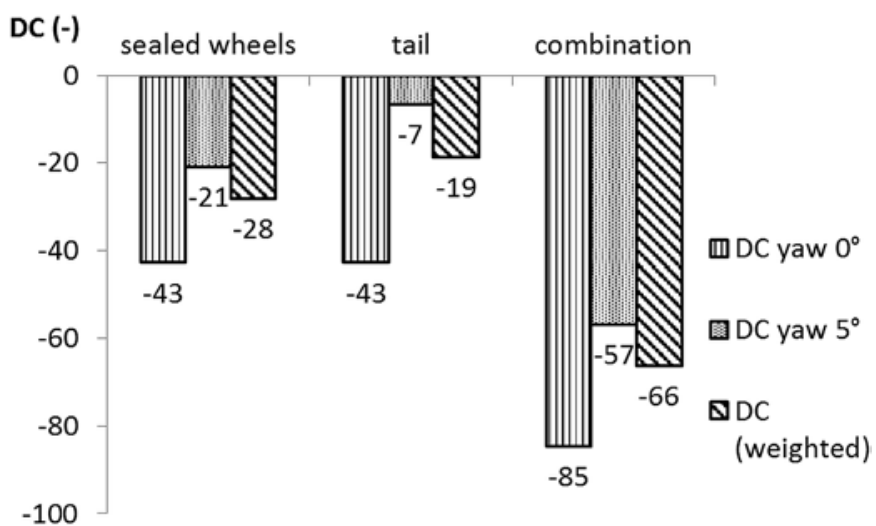

Fig. 7. Drag values in $D C$

$$
D C=1000 \cdot \Delta C_{d}
$$

where $\Delta \mathrm{C}_{\mathrm{d}}$ is the difference of $\mathrm{C}_{\mathrm{d}}$ for reference vehicle and vehicle equipped with devices [-].

Fig. 6 and Fig. 7 express the influence of aerodynamic devices on the drag coefficient. From this graphic evaluation the influence rate of each device in the absolute expression as $\mathrm{C}_{\mathrm{d}}$ or in the difference as DC is clear. The lower rates of coefficient are better because they are directly proportional to the aerodynamic drag. With decreasing of the drag also truck fuel consumption decreases and that is the main reason of testing and using aerodynamic devices. As the main result value we consider the weighted $\mathrm{C}_{\mathrm{d}}$ or DC. Theoretically it reflects light crosswind wind influence which acts during a vehicle is moving. The best result reaches combination of both devices at the value of -66 DC. 
Higher influence reflects at the yaw of $0^{\circ}$ what is probably due to the bigger surface where the crosswind at the yaw of $5^{\circ}$ can act. Sealed wheels reach higher decreasing of $\mathrm{C}_{\mathrm{d}}$ than tail without enlarging the truck length and side surface and without decreasing manoeuvrability (tail does it) $[11,13,14]$.

\section{Summary}

During measuring and its evaluation we took the view that using a model vehicle of higher scale would probably get results with accuracy. But the measured values present common rates of $C_{d}$ used in the scientific area of the ground vehicles. Next measurement on the real sized vehicle on real road would be more appropriate. According to the comparison of real condition and this measuring the differences are: static wheels on the model and a static road (mat) in a wind tunnel. These two facts should have influence on smaller differences to $C_{d}$ values of the real truck set $[15,17,18]$.

The results provide values which reflect negligible effect on the aerodynamic drag of truck sets. They show that using these devices consumed fuel can be spared and so the effectiveness of the transport duty and of a vehicle can be increased.

\title{
References
}

1. Barnard R H. Road vehicle aerodynamic design - an introduction. St. Albans: Mechaero Publishing, 2001.

2. Choi H, Lee J, Park H. Aerodynamics of Heavy Vehicles. Annual Review of Fluid Mechanics 2014; 46: 441-468, http://dx.doi.org/10.1146/ annurev-fluid-011212-140616.

3. Davila A. Report on Fuel Consumption. Project 233683 SARTRE, ECE, 2013.

4. Ghoreyshi M, Kim A D H, Jirasek A, Lofthouse A J, Cummings R M. Validation of CFD simulations for X-31 wind-tunnel models. Aeronautical Journal 2015; 119 (1214): 479-500.

5. Gunes D. On the similarity of wind tunnel experiments and numerical simulation of heavy-duty trailer flow. Progress in Computational Fluid Dynamics 2010; 10 (3): 168-176, http://dx.doi.org/10.1504/PCFD.2010.033328.

6. Hakansson Ch, Lenngren M J. CFD Analysis of Aerodynamic Trailer Devices for Drag Reduction of Heavy Duty Trucks. Goteborg: Chalmers University of Technology, 2010.

7. Hausberger S, Rexeis M, Blassnegger J, Silberholz G. Evaluation of fuel efficiency improvements in the Heavy-Duty Vehicle (HDV) sector from improved trailer and tire designs by application of a new test procedure. Graz: TU Graz, 2011.

8 Holt J, Garry K, Velikov S. A wind tunnel investigation into the effects of roof curvature on the aerodynamic drag experienced by a light goods vehicle. International Journal of Vehicle Design 2015; 67 (1): 45-62, http://dx.doi.org/10.1504/IJVD.2015.066478.

9. Hromadko J, Miller P, Honig V. Use of the vehicle movement model to determine economic and environmental impact caused by separate vehicles. Eskploatacja I Niezawodnosc - Maintanence and Reliability 2009; 1: 70-73.

10. Hubova O, Konecna L, Lobotka P. Influence of Walls and Ceiling on a Wind Flow in BLWT Tunnel. Applied Mechanics and Materials 2014; 617: 257 - 262, http://dx.doi.org/10.4028/www.scientific.net/AMM.617.257.

11. Jazar R. Vehicle Dynamics, Theory and applications. Springer Science + Bussines Media, 2009.

12. Kendra M, Babin M, Barta D. Changes of the infrastructure and operation parameters of a railway line and their impact to the track capacity and the volume of transported goods. Procedia - social and behavioral sciences 2012; 48: 743-752, http://dx.doi.org/10.1016/j. sbspro.2012.06.1052.

13. Liscak S, Matejka R, Rievaj V, Sulgan M. Operational characteristics of vehicles. Zilina: Edis publisher, 2004.

14. Levulyte L, Zuraulis V, Sokolovskij E. The research of dynamic characteristics of a vehicle driving over road roughness. Eksploatacja i Niezawodnosc - Maintenance and reliability 2014; 16 (4): 518-525.

15. Parczewski K, Wnenk H. Using mobile scaled vehicle to investigate the truck lateral stability. Eskploatacja i Niezawodnosc - Maintanence and Reliability 2013; 4: 414-420.

16. Rajamani R. Vehicle dynamics and control. New York: Springer, 2012, http://dx.doi.org/10.1007/978-1-4614-1433-9.

17. Watkins S. Wind-Tunnel Modelling of Vehicle Aerodynamics: with emphasis on turbulent wind effects on commercial vehicle drag. Melbourne: Victorian University of Technology, 1990.

18. Wong J Y. Theory of ground vehicles. Ottawa: John Wiley \& Sons. Inc., 2001.

19. Zvolensky P, Stuchly V, Grencik J, Poprocky R. Evolution of maintenance systems of passenger and freight wagons from the ECM certification point of view. Communications: scientific letters of the University of Zilina 2014; 16: 40-47.

20. Zuraulis V, Sokolovskij E, Matijosius J. The opportunities for establishing the critical speed of the vehicle on research in its lateral dynamics. Eksploatacja i Niezawodnosc - Maintenance and Reliability 2013; 15 (4): 312-318.

\author{
Tomas SKRUCANY \\ Branislav SARKAN \\ Jozef GNAP \\ Department of Road and Urban Transport \\ Faculty of Operations and Economic of Transport and \\ Communications \\ University of Žilina \\ Univerzitná 1, 01026 Žilina, Slovakia \\ E-mail: tomas.skrucany@fpedas.uniza.sk \\ branislav.sarkan@fpedas.uniza.sk, jozef.gnap@fpedas.uniza.sk
}

